\title{
Analysis of Psychological and Verbal Pattern of Female Protagonists in Anita Desai's Fiction
}

\author{
Dr. Pinky
}

PGT in English, Doon International School, Karnal, Haryana, India

\begin{abstract}
Anita Desai likes to reach the depth of human psyche. Anita Desai discards the traditional, worn out eternal realism and dives deep into the minds of her protagonists to examine the values and principles that they live by. Even when she probes man's relationship with his socials milieu, her stress falls on her characters' private instincts and intuitions, feelings and emotions. All her characters are shown on one hand struggling with the changed realities of Indian life. In their neurotic condition they fail to adjust themselves to the harsh realities of life and they react aggressively and sometimes they don't react and agree to strike a compromise with their situation after getting no other way. But both situations cause psychological disturbance and this is the case with Anita Desai's protagonists.
\end{abstract}

Keywords : Psychology, Verbal, Pattern, Instinct, Neurotic, Frustration

Anita Desai is considered the writer who introduced the psychological novel in the tradition of Virginia Woolf to India. She is also a pioneer of writing about feminist issues. Anita Desai is not interested so much in registering surface realities as in the probing of inner truths lying under the surface level. Her pioneering contribution lies in sketching the selfconsciousness of her oversensitive characters, who seek fulfillment in the assertion of their self-identity. Thus critics have also tried to highlight her interest in the individual as a significant part of society, the emphasis always being on the individual rather than society. In an interview, Anita Desai admits that her primary interest will always be in the in individual rather than in a mass of people (Sapth 58-63).

Anita Desai discards the traditional, worn out eternal realism and dives deep into the minds of her protagonists to examine the values and principles that they live by. Even when she probes man's relationship with his socials milieu, her stress falls on her characters' private instincts and intuitions, feelings and emotions. The eternal features of personality and the outer lineaments of the visible world interest her only as the starting point of the more important voyage within, so that she can hold the focus on "nine tenth of the ice-berg that is submerged beneath the one-tenth visible portion we call reality" (Dalmia). As rightly noted by Madhusudan Prasad, Anita Desai probes her characters' "emotional ecology, their rumbling, turbulent inner world" (xiii).

As a part of her endeavour to supplement the outer realism with the inner one, Anita Desai likes to reach the depth of human psyche. She remarks in an interview given to Jasbir Jain, "It is depth which is interesting delving deeper and deeper in a character or a scene rather than going around and about it" (6169). Anita Desai has delineated in her novels problems and plight of alienated and frustrated individuals caught in the crisis of a changing society. She tries to give an explanation of this frustration, 
which is possible through psychology. Ramesh Srivastava summaries,

It is not only the subject matter, characterization and in presenting the atmosphere of mind but also in the use of narrative technique, symbols, images and the disturbed time-scheme that Anita Desai deserves to be called a psychological novelist (xxvi).

All her characters are shown on one hand struggling with the changed realities of Indian life and on the other hand with the psychic conflict of personal origin. Society compels every individual to repress instinctual urges and the desire for the freedom of will in the name of upholding its ideals and expectations which are often anti-human and oppressive. At a certain point of time when these conflicts become too pronounced, their patience gives a way and they try to make effort to seek neurotic solutions to their problems. In their neurotic condition they fail to adjust themselves to the harsh realities of life and they react aggressively and sometimes they don't react and agree to strike a compromise with their situation after getting no other way. But both situations cause psychological disturbance and this is the case with Anita Desai's protagonists. Sigmund Freud also shows the dependence of an individual on the external environment and two important possibilities may be the sequel (i) reduction of tension through gratification of instincts (2) insecurity as a result of frustration. If the individual is confronted with the latter by and by, defence mechanism fails and the individual is about to enter in neurotic stage (106).

Neurosis is possibly seen manifested in the form of alienation and fear. The alienation takes the form of loneliness, withdrawal from active interest in other people absence of relationships and rejection of social customs, institutions, values and norms. Karen
Horney attributes alienation to environmental influences (39). The kind of alienation that Anita Desai's protagonists suffer from, they are deeply conscious of their senses of emptiness and meaninglessness and much more than this, their sense of helplessness and not being able to mould the outer reality after their hearts' desire.

Sometimes Anita Desai's characters become schizophrenic. In schizophrenia an individual does not suffer from a conflict between difficult choices, but rather a double vision of life. Due to the conditions that spell the psychological disorder of neurosis and schizophrenia, Anita Desai's characters feel neglected, discarded and disowned, and naturally find their social surroundings unattractive and tedious. The consequence of an advanced state of neurosis is violence-violence inflicted on others or oneself. Anita Desai's protagonists when they find themselves trapped between two alternatives which are both unsatisfying, choose violence as their recourse and even go to the length of killing another individual or themselves. N.R Gopal also remarks in this regard,

Anita Desai not only explores and portrays the feminine psyche of a common woman but also of the sub-normal bordering of abnormal women. These are women who because of various factors are under so much mental stress that they cannot be called insane but then certainly they are not normal (4).

Verbal pattern used by the Characters unfailingly pushes them to the region of mental torture. Although they argue with each other only for the sake of saying but one is totally unaware of the fact that whether the other person is digesting it or not. But the hypersensitivity of Anita Desai's characters seems to be a hurdle in digesting anything easily. Actually, they are extremists in nature - 
hypersensitive or insensitive. Whenever hypersensitivity and insensitivity stand against each other, the result is - failure of understanding. The more sensitive a person is, the more frustrated he will be and the more insensitive a person is, the less frustrated he is. After examining the gallery of Anita Desai's characters, it is observed that their normal discourses always end in abnormal situation and echo of their hot words keep their mental torture afresh. We find this killing art in many characters presented by Anita Desai in her novels. This paper includes Anita Desai's two novels Where Shall We Go This Summer? and Clear Light of Day.

Anita Desai's Where Shall We Go This Summer? describes a disillusioned woman named Sita who rebels against her present state and wishes to cut herself off from the main stream of life and desires to return back to her childhood past, her parental house, Manori. She harbors grudge against her fifth pregnancy. She had enjoyed her earlier pregnancies. Perhaps she wants her dreams to be fulfilled through children. But they not only separate themselves from her but they reject her also. Outwardly, anyone can feel jealous to see her happy world, full of children and a nice husband but for Sita it is a world of sufferings and tortures because she lacks a sense of belongingness. From the early childhood to her married life she does not have a home of her own. This damages her senses of belongingness, "Belongingness.... means a subjective feeling of one's personal involvement to the extent that one feels himself to be an integral part and indispensable part of the system" (Where Shall We Go This Summer? 31. Further references to Where Shall We Go This Summer? will appear as page numbers preceded by WSWGTS). But from her very childhood she is forced to think herself an outsider of the familial system by her own parents. Therefore, her frustration germinates from the very beginning of her life.
Her disillusion with her father also sharpens her sense of frustration. Sita's father is exclusively responsible for ingraining insecurity in her by his negligence. There is always an "impossibility of talk between her and her father" (WSWGTS 31-32). During these particular moments, nobody comes near her to puncture her balloon of frustration. She is bound to remain silent. She fails to open up. With this experience she fails to feel personal involvement in life. Erich Fromm feels that by getting attached ourselves to another person, alienation can be cured.

There is only one possible productive
solution for the relationship of
individualized man with the world: his
active solidarity with all men and his
spontaneous activity, love and work, which
unite him again with the world not by
primary ties but as a free and independent
individual (96).

But Sita is getting ahead in isolation. After her father's death Sita gets under way of thinking about her isolation to be relieved through deserting island at any cost and she does it by getting married. But Sita's destiny dupes her again. As her new life begins on the mainland she becomes ecstatic. Sita being a lonely young woman, looks up to her husband Raman as her God. Raman, however, does not get ready to honour her respect. Instead of satisfying her psychologically, he enhances her mental tortures. Raman has his own ideas to deal with her. Normally, he does not react and he also dislikes Sita's lack of control instead of understanding her reaction. As Sita argues, "what do you know about my condition?" She flared, "I've told you-I've tried to tell you but you haven't understood a things..." (WSWGTS 79). Raman also accepts himself that "I don't understand much ..." (WSWGTS 33). Humanity is replaced by hatred in Raman with the passage of time: "He was repelled, he turned away, not being able to see her 
any more for hatred to her. He hated her, hated her talk." (WSWGTS 33). Sita also begins to realize that life is but "a crust of dull tedium of hopeless disappointment" (WSWGTS 33). Her married life is also proved to be an extension to continue her silence. And the only option to revolt against her frustration for her is to go back to the island.

Her wish of not going birth to a child also reflects her desire of violating the marriage deed between her and Raman. She is of the view that if she reaches the island, every problem will be solved. On the island she dives deep inter the memories of the past. But how long can she be in the realm of memories. She cannot run away from her life as a mother and a housewife. But soon she realizes soon that revisiting the past in impossible: "If it had ever existed-black, sparkling and glamorous in her memory- it was now buried beneath the soft gray- green mildew of the mansoon, chilled and chocked by it" (WSWGTS 39).

Sita wants her daughter to be a creative artist but Menaka does not accept her mother's eccentric temperament: "She had had enough of her mother's disorder and nonsense-she would escape it wholly" (WSWGTS 103). She wants to identify with her father. This very attitude of Menaka shatters all hopes of Sita. Through letter Menaka urges her father to take them back to Bombay without giving any prior information to her mother. Sita miserably says, “Menaka didn't tell me she had written you. I don't know anything about if" (WSWGTS 117). But instead of pacifying her Raman aggravates her through his dialogues: "There was nothing you could do for her..." (WSWGTS 117). And again he argues unsympathetically, "But you know you must leave you will have to come back"...."you must", he said, she shook her head. It seemed to her that he was always saying to her, "you must" (WSWGTS 140). She is full of self-contempt as she fails in playing her role as a mother, a wife, a daughter and a woman. Now she feels strongly against the social values imposed by the society. Her rage externalizes her inner turmoil: "It was as though for seven months she had collected inside her resentments; her fears, her rages and now she flung them outward, flung them for her" (WSWGTS 140).

Failure in life makes her vindictive. As a result Sita becomes a rebellious. But in the end of the novel, it is clear that Sita compromises with her situation and gets ready to go back to the world in which she is nothing but a non-entity.

In Clear Light of Day, there are four brothers and sisters-Raja, Bim, Tara and Baba. The childhood closeness is shattered gradually as the children grow older. They begin to feel their different dreams and aspirations and the ways to fulfill them.

Among all the children, the most affected personality is Bim. In fact, Raja and Tara imitate unknowingly their parents' unfaithfulness and selfishness in their relationships but a Bim remains attached to all surrounding her. Hence, she feels mental torture when others show their selfishness and unfaithfulness. After the death of their parents, Bim was bound to think about managing both ends meet as Raja was selfishly uplifting himself through the aristocratic Hyder Ali and in the same way Tara was passing her time with Bakul. At this juncture Bim takes up a teaching job after finishing her education and also takes care of Baba, a mentally retarded brother and Aunt Mira, a distant cousin of her mother. R. S. Pathak observes:

The period of that lies in between-the growing consciousness and search for individuality of adolescence- fails to provide of childhood to the later stage of adulthood, causing deep psychological trauma and stress (224).

Tara and Raja never realize about Bim's agony. Tara is enjoying her married life while Bim has no time for her own love and life due to the responsibilities. The 
irony is that in spite of her immolation for the family, no one is here to sacrifice anything for her. This is what alienates her to the world of Baba. Bim sense of separation from her brother and sister heightens in her a sense of frustration and disintegration. Bim's pathetic conversation with Baba discloses the disorganized state of the family that disturbs her most: "So now there are just you and I left Baba,... Does the house seem empty you? Everyone's gone, except you and I. They won't come back. We'll be along now"182 (Clear Light of Day 27). She feels that all her relations to Tara, Bakul and Raja are means to torment her. Nevertheless, the novel ends with a positive note. Her wounded self moves towards the realization of a new self. At last she makes a positive effort to come out of the trauma in which she was caught. S. Indira rightly considers, "Bim seems to be offering the morning hymn,' to 'Time' as it paves the way for her regeneration so that she becomes a fulfilled individual who experience love and peace" (Clear Light of Day 28).

By exploring the mind of her characters especially women, Anita Desai is not just examining them from a psychological point of view, but showing us social reasons why her characters are pushed into the position of helplessness. It is acceptable for an Indian woman to search no other life or occupation outside home after her marriage. When she is ignored emotionally, she withdraws into the world of her own and her insensitivity makes her solitary to the point of being neurotic.

\section{REFERENCES}

[1]. Dalmia, Yashodhara "An Interview with Anita Desai" The Times of India. 29 April 1979. https://timesofindia.indiatimes.com/archive.cms

[2]. Desai, Anita. Clear Light of Day. New Delhi: Arnold Heineman 1980. Where Shall We Go This Summer?. Delhi: Orient Paperbacks, 1982
[3]. Freud, Sigmund. New Introductory Lectures on Psychoanalysis. Trans. James Strachey. Harmondsworth: Penguin, 1973.

[4]. Fromm, Erich. The Art of Loving. London: Union Paperbacks, 1976.

[5]. Gopal, N.R. A Critical Study of the Novels of Anita Desai. New Delhi: Atlantic, 1995.

[6]. Horney, Karen. New Ways in Psychoanalysis. New York: Norton, 1939.

[7]. Jain, Jasbir, “Anita Desai: Interviewed" Rajasthan University Studies in English. Vol 2. 1979.

[8]. Prasad, Madhusudan (Ed). "Introduction". Perspective on Kamla Markandaya. Ghaziabad: Vimal, 1984.

[9]. Sapth, Ketaki "It's Fatal to Write With an Audience Mind," an interview with Anita Desai Imprint , June. 1984.

[10]. Srivastava, Ramesh K. (Ed). "Anita Desai at Work: An Interview" Perspectives on Anita Desai. Ghaziabad: Vimal, 1984.

\section{Cite this article as :}

Dr. Pinky, "Analysis of Psychological and Verbal Pattern of Female Protagonists in Anita Desai's Fiction", International Journal of Scientific Research in Science and Technology (IJSRST), Online ISSN : 2395-602X, Print ISSN : 2395-6011, Volume 6 Issue 2, pp. 306-310, March-April 2019. Available at doi : https://doi.org/10.32628/IJSRST196254 Journal URL : http://ijsrst.com/IJSRST196254 